\title{
Support for students with disabilities in the UK universities
}

\author{
Natalia Lukianova ${ }^{1,2, a}$, Elena Fell ${ }^{1}$ \\ ${ }^{1}$ Tomsk Polytechnic University, 634050 Lenin Avenue, 30, Tomsk, Russia \\ ${ }^{2}$ Tomsk State University, 634050 Lenin Avenue, 36, Tomsk, Russia
}

\begin{abstract}
This paper examines the current status of higher education provision for disabled students in the UK universities. Commenting on the dynamics of relevant legislation in the Introduction, the authors survey the types of support that disabled students are entitled to in accordance with the Equality Act, 2010, comprising important pieces of legislation that redefine the role of a disabled person in the British society. The article touches on the financial support that disabled students receive in Britain, namely a Disabled Students' Allowance (DSA), giving figures for the academic year 2016-17. Peer relations between ablebodied and disabled students are also discussed.
\end{abstract}

\section{Introduction: Against discrimination in universities.}

As Riddell et al. note, 'prior to 1993, higher education was largely inaccessible to disabled people and any adjustments made were at the good will of staff and students [1].

In a small number of universities personal assistants and volunteers were available for students with various disabilities, but these initiatives were 'the exception rather than the rule, and the general assumption was that university was not the place for disabled people [1].

The situation changed in 1993 with the creation of Skill (the National Bureau for Students with Disabilities), a voluntary organisation promoting access to higher education for disabled people. Following this, the English Higher Education Funding Council (HEFCE) and the Scottish Higher Education Funding Council (SHEFC) started funding institutions so that they would develop facilities for disabled students and make university education accessible to them.

Disability Discrimination Act 1995[2], which placed responsibility on universities to create an inclusive environment for disabled students, was another important step forward for the inclusion of disabled people in higher education. Legislation continued to evolve, and Part 4 of the Disability Discrimination Act [2] made it illegal to discriminate against disabled students or prospective students in all aspects of university life. As Mary Fuller et al. observe, 'this shifts the focus from recruitment and physical access towards the removal of barriers in relation to teaching, learning and assessment [3].

This shift of focus has changed the concept of discrimination and redefined the position of a disabled

a Corresponding author: lukianova@tpu.ru person in the learning environment. Discriminating against a disabled person is no longer merely denying him or her access to a degree course. Not providing a wheelchair access to the building is discrimination; not making a reasonable adjustment for a student with hearing impairment is discrimination - in other words, not making effort to include someone in the educational process is discrimination as everyone, including people with disabilities, have the right to access premises, events and facilities and equally benefit from all forms of social engagement.

The Disability Discrimination Act 1995 was replaced by the Equality Act 2010 which reinforced further the rights of disabled people and redefined their position in society [4].

\section{Equality Act 2010: disability is a protected characteristic}

In 2009 the UK ratified the UN Convention on the rights of people with disabilities. This means that the UK government agreed that they would work to:

According to the UN Convention on the rights of people with disabilities, 'the education system at all levels [must be] inclusive and geared towards supporting disabled people to achieve their full potential and participate equally in society' [5].

Under the Equality Act 2010, disability is a protected characteristic, which means that it is unlawful to discriminate against people who are disabled. Disability is defined in the Equality Act as: 'a physical or mental impairment which has a substantial and long-term adverse effect on your ability to carry out normal day-today activities'[6] 
For someone to be classed as disabled, they do not need to have a medically diagnosed cause for their impairment. What is important is the effect the impairment has on their daily life. Multiple Sclerosis, HIV, Cancer and blindness are examples when people suffering from these conditions would be automatically regarded as disabled. Other, less obvious impairments include the following: asthma; diabetes; mental health conditions (schizophrenia, panic attacks, anxiety, phobias, depression, obsessive compulsive disorders, bipolar affective disorder, eating disorders); muscular dystrophy; mobility difficulties; sensory impairments (affecting sight or hearing); learning difficulties (dyslexia and dyspraxia); motor neurone disease. Conditions that are accompanied by fatigue or pain also fall under the definition of disability. Also, if someone was disabled in the past, he is she still remains protected [6].

For a disabled student to be protected from discrimination means to be protected from being treated unfairly by an education provider. This includes being put at a disadvantage (either intentionally or unintentionally) when compared with able-bodied students.

There are various types of discrimination that are illegal under the Equality Act.

An example of direct discrimination would be refusing a blind person to do an IT course because the education provider (incorrectly) assumes that a blind person would not be able to use computers.

Discrimination by perception would happen if a candidate were not offered a place on a degree course because the university suspects they have a mental health illness (they may or may not have one) and they think that the prospective student may not be able to complete the course.

Discrimination by association is discrimination against someone because they have a disabled partner, relative or friend, or if they are a carer of a disabled person. For example, if a candidate is refused a place in an apprenticeship scheme because the provider is aware of the candidate's caring responsibilities for a disabled spouse.

Indirect discrimination takes place is when a practice or policy has a worse effect on some people than others. For example, if a university expects students to register for units online, this may be discrimination of a student with a visual impairment who cannot use the system.

Discrimination arising from a disability would occur if the university took steps to exclude a student from the course because they were absent for a long period due to depression and anxiety.

Disabled students are also protected against harassment violating their dignity which may include abusive words, physical gestures, facial expression, jokes, pranks, mimicry [6].

\section{Universities' responsibility towards disabled students}

The Equality Act 2010 requires universities not to discriminate against disabled students. Section 20 of the Equality Act 2010 states that all Higher Education Institutions must make 'reasonable adjustments' for students concerning teaching and assessment methods and processes; access to lecture theatres, laboratories and teaching rooms; provision of auxiliary aids such as hearing loops, information in accessible formats, as well as providing Non Medical Assistance [7].

It is important to highlight the fact that the university's duty to make provisions for its disabled students is anticipatory and all adjustments should be in place before any individual student requires them. 'There is no legal defence for the failure of an institution to make a reasonable adjustment. This would be interpreted as discrimination under Section 21 of the Act [8].

\section{Reasonable adjustments for disabled students: practical support}

Members of University teaching staff are expected to be aware of having to make reasonable adjustments in order to accommodate disabled students' special needs. Examples of inclusive teaching (listed on the site of the University of Cambridge [9]) are as follows:

In lectures, extra support means that the teacher must take into account that some students may find it hard to listen and take notes at the same time, and then be required to do something else as well, like following slides or responding to questions. In case such students are present at the lecture, the lecturer should not request his or her class to engage in more than one (or two) learning activities at once. Also, the lecturer is required to provide lecture handouts 24 hours in advance for the sake of his or her students who may have disabilities.

During discussions, the lecturer is expected to provide extra help by explaining clearly the structure of activities during the discussion. For example, if there is a deaf student in the group, the lecturer must state at the start of each session that each participant, before he or she begins to speak, will need to attract the deaf student's attention so that he or she could lip-read.

When a disabled student is preparing for presentations, the lecturer must offer additional time and ask if he or she needs support. Additional practice sessions are recommended in these situations and it is important to make sure that the subsequent group discussion is constructive and well planned.

Disabled students have the right to receive the same level of support wherever they are learning (i.e. during the year abroad) from everyone who teaches them.

Generally, disabled people will need more assistance in an unfamiliar environment, so whilst planning fieldwork or work in laboratories the leader must ensure that disabled students can access support that they need.

For example, it may be good to have the equipment partially set up for a disabled student in a laboratory however, other students should not be used as assistants whilst this is being done. All instructions that are presented should also be available in written format. 
Libraries should offer specialist equipment such as scanner system, Braille printer, a voice-synthesiser, closed circuit television reader, screen-reading software, screen magnifier.

In libraries, there should be good physical access to resources or alternative strategies should be in place if physical access is not possible. If access is not possible to some areas, this should be indicated clearly. Besides, all signs and notices should be visible and very clear.

Librarians or library assistants should offer to fetch books from shelves if a disabled person cannot reach the shelf.

Also, all catalogues must be accessible and the library should be able to accommodate extended loan periods for those students who need extra time to use books, and access to the library for the students' assistants should be allowed.

\section{Disabled Students' Allowance (DSA) in 2016 to 2017 academic year.}

Currently, a disabled higher education student in England is entitled to a Disabled Students' Allowance (DSA) [10] with the view of covering the extra costs he or she may incur because of his or her disability. Unlike many other benefits in Britain, DSA is not means tested, does not depend on the student's household income, and the amount payable to the student depends on his or her individual needs. DSA is not a loan and does not need to be repaid, can be claimed by both full time and part-time students, but the amount payable to part-time students is adjusted accordingly. This money can be used to pay for specialist equipment, non-medical helper services, and other expenses including travel or a purchasing a new computer. This allowance is paid either into the student's bank account or to the organisation that provides the service or supplies specialised equipment. Table 1 shows how much a disabled student can get in 2016 to 2017 academic year.

Table 1. Disabled Students' Allowance for 2016 to 2017 academic year [10].

\begin{tabular}{|l|l|l|l|}
\hline & $\begin{array}{l}\text { Specialist } \\
\text { equipment } \\
\text { allowance }\end{array}$ & $\begin{array}{l}\text { Non- } \\
\text { medical } \\
\text { helper } \\
\text { allowance }\end{array}$ & $\begin{array}{l}\text { General } \\
\text { allowance }\end{array}$ \\
\hline $\begin{array}{l}\text { Full-time study } \\
\text { (undergraduate) }\end{array}$ & $\begin{array}{l}\text { Up to } \\
£ 5,212 \text { for } \\
\text { the whole } \\
\text { course }\end{array}$ & $\begin{array}{l}\text { Up to } \\
£ 20,725 \text { a } \\
\text { year }\end{array}$ & $\begin{array}{l}\text { Up to } \\
\text { year }\end{array}$ \\
\hline $\begin{array}{l}\text { Part-time study } \\
\text { (undergraduate) }\end{array}$ & $\begin{array}{l}\text { Up to } \\
£ 5,212 \text { for } \\
\text { the whole } \\
\text { course }\end{array}$ & $\begin{array}{l}\text { Up to } \\
£ 15,543 \text { a } \\
\text { year }\end{array}$ & $\begin{array}{l}\text { Up to } \\
\text { year } \\
\text { yea a }\end{array}$ \\
\hline Postgraduates & \multicolumn{2}{|l|}{ Up to $£ 10,362$ a year in total } \\
\hline
\end{tabular}

\section{Who qualifies for Disabled Students' Allowance (DSA)?}

Proving one's eligibility for DSA is a straightforward process if a student is physically disabled, partially sighted, blind, hard of hearing, or deaf. A letter from his or her doctor or a specialist is considered sufficient medical evidence in these situations and also if the student suffers from a mental-health condition [11].

However, a full diagnostic report is required in case of the student suffering from dyslexia or other specific learning difficulties. Such a report must be written by either a practitioner psychologist or a specialist teacher who must have a current Assessment Practising Certificate [11].

Following the receipt of the student's application form and medical evidence, the student may be asked to book a Study Needs Assessment with an experienced Needs Assessor during which there will be an informal discussion regarding equipment and support that the student would need during their time at university [11].

\section{Able-bodied and disabled students: peer relations}

The issue of disabled students' wellbeing is not limited to the physical provision of services and equipment. It concerns social relations as well, and peer relations in particular. In terms of attitudes towards disabled peers, De Boer, A., Pijl, S.J., \& Minnaert, A. (2012) found that able bodied students' attitude towards other students with disabilities is neutral rather than negative or positive [12].

In the recent years a significant body of research investigating issues of friendship between able bodied and disabled people has been created (e.g. Petrina, Carter, \& Stephenson, 2014; Salmon, 2013; Worth, 2013; Castrodale and Zingaro, 2015).

The problem of social informal interactions and disability has been discussed from various perspectives. Whilst Reinders (Reinders, 2008) presents friendship between able bodied and disabled persons not as an equal and mutually beneficial exchange but almost as an act of charity directed towards the disabled, De Boer, Pijl, Post, \& Minnaert (De Boer, Pijl, Post, \& Minnaert, 2013) offer a view of disability as abnormality that can be partially remedied by friendship with normal, healthy people. To counteract this condescending attitude toward disabled people, Castrodale and Zingaro explore 'friendship as an analytic lens to unpack the nexus of able-bodied and disability-related experiences between friends in university settings...seeking definitions of friendship that acknowledge the mutual benefits afforded by friendship'[13].

In Castrodale and Zingaro's account, friendship becomes a site where disability is interrogated, but so is abled-bodiedness and one's personal understanding of both is explored. Friendship reveals how one's perception of one's own disability contrasts with dominant societal views of that disability which view a disabled person as someone who needs fixing. According to the authors, friendship between disabled and able-bodied individuals can serve as a platform for a wider social disability-related engagement leading to 'disability-related equity politics, advocacy, and activism to reject understandings of disability as a personal 
tragedy and resist related practices limiting the full societal participation/inclusion of disabled persons.' (Castrodale and Zingaro 2015) [13].

\section{Conclusion}

In Britain, there has been significant progress in making higher education accessible for people with disabilities. A typical university offers advisory service to disabled students (or prospective disabled students) giving them information and facilitating support for those who have e.g. 'sensory or mobility impairments, long-term health conditions, specific learning difficulties, autistic spectrum conditions or mental health difficulties [14] The Disability Advisory Service at the University of Oxford, for example, can direct the student to disability contacts - nominated members of staff who coordinate advice and support for students with disabilities throughout the University. The disability advisor helps the student with all processes involved in accessing the help that is available, such as disclosing a disability; providing evidence of one's disability; applying for funding; arranging a study needs assessment; agreeing the disabled student's Student Support Plan (SSP).

However, despite efforts that university staff are expected to make in order to make disabled students feel included, reality can be different. 'Student Rosie Watson felt humiliated and let down when her tutors failed to take into account her deafness', Afua Hirsch and Alice Lagnado report [15]

Rosie started a degree course at Durham University, and was assessed. She received a laptop and was given the support of a note-taker. However, she felt humiliated by lecturers who did not take her needs into account by shouting at her and not preparing sufficient resources so that she could understand for example what was being said on a television screen. She complained and as a result was offered counselling.

Rosie claimed discrimination on grounds of disability and received $£ 25,000$ from Durham University as compensation, but disabled students are still finding it difficult to benefit from university experience and drop out of courses.

Unfortunately, 'a combination of "tick-box" approaches to achieving disability equality, failures by some universities to implement legally required measures, and failures by the Student Loads Company are all hindering disabled students'[15].

\section{Acknowledgment}

This research was supported by the grant awarded by Russian Science Foundation (project №16-18-00016)

\section{References}

1. S. Riddell, T. Tinklin, A.Wilson, Disabled Students in Higher Education. Perspectives on widening access and changing policy (Routledge, Oxon, NY, 2005)

2. Disability Discrimination Act (1995). URL: http:/www.legislation.gov.uk/ukpga/1995/50/conte nts/enacted

3. M. Fuller, J. Georgeson, M. Healey, A. Hurst, K. Kelly, S. Riddell , H. Roberts , E. Weedon. Improving Disabled Students' Learning: Experiences and Outcomes (Improving Learning) Routledge (2009).

4. Information and guidance on the Equality Act 2010, including age discrimination and public sector Equality Duty. (2010) URL: https://www.gov.uk/guidance/equality-act-2010guidance

5. Equality and Human Rights Commission, Article 24 Education.

URL :

http://www.equalityhumanrights.com/private-andpublic-sector-guidance/public-sectorproviders/human-rights-guidance/a-guide-to-the-undisability-convention/part-2-know-yourrights/article-24-education

6. Understanding the Equality Act: information for disabled students/ URL : http://www.disabilityrightsuk.org/understandingequality-act-information-disabled-students

7. Equality Act (2010) URL: http://www.legislation.gov.uk/ukpga/2010/15/sectio $\mathrm{n} / 20$.

8. Code of Practice: Reasonable Adjustments for Disabled Students. General Board. URL: http://www.student-

registry.admin.cam.ac.uk/files/codeofpractice_reaso nableadjustmentsfordisabledstudents_14-15.pdf

9. Learning disability.URL : http://www.disability.admin.cam.ac.uk/staffsupporting-disabled-students/teaching-disabledstudents/inclusive-teaching

10. Disabled Students' Allowances (DSAs). URL: https://www.gov.uk/disabled-students-allowancesdsas/what-youll-get

11. Extra help - Disabled Students' Allowances. URL: http://media.slc.co.uk/sfe/1617/ft/sfe_disabled_stude nts_allowance_guide_1617_d.pdf

12. A.De Boer, S. J.Pijl, A. Minnaert, International Journal of Disability Development and Education 59(4), 379-392 (2012)

13. M. Castrodale, D. Zingaro You're such a good friend: A woven autoethnographic narrative discussion of disability and friendship in Higher Education, Disability Studies Quarterly (2015), URL: http://dsq-sds.org/article/view/3762/3827

14. Disability. URL : https://www.ox.ac.uk/students/wel fare/disability?wssl=1

15. Special educational needs. Study shows more disabled students are dropping out of university (2010).

URL: http://www.theguardian.com/education/2010/may/2 5/diabled-student-drop-out-university-increase 